九州大学学術情報リポジトリ

Kyushu University Institutional Repository

\title{
Identification of the Endophytic Bacterial Isolates and their in vitro and in vivo Antagonism against Ralstonia solanacearum
}

\section{Long, Hoang Hoa}

Laboratory of Plant Pathology, Division of Plant Pathology and Pesticide Science, Department of Applied Genetics and Pest Management, Graduate School of Bioresource and Bioenvironmental

Sciences, Kyushu University

Furuya, Naruto

Laboratory of Plant Pathology, Division of Plant Pathology and Pesticide Science, Department of Applied Genetics and Pest Management, Faculty of Agriculture, Kyushu University

Yamamoto, Ichinari

San-In Kensetsu Kougyou Co., Ltd

Takeshita, Minoru

他

https://doi.org/10.5109/4583

出版情報: 九州大学大学院農学研究院紀要. 49 (2)，pp.233-241，2004-10-01. Faculty of Agriculture, Kyushu University

バージョン：

権利関係: 
J. Fac. Agr., Kyushu Univ., 49 (2), 233-241 (2004)

\title{
Identification of the Endophytic Bacterial Isolates and their in vitro and in vivo Antagonism against Ralstonia solanacearum
}

\author{
Hoang Hoa LONG', Naruto FURUYA*, Daisuke KUROSE', \\ Ichinari YAMAMOTO ${ }^{2}$, Minoru TAKESHITA \\ and Yoichi TAKANAMI
}

\begin{abstract}
Laboratory of Plant Pathology, Division of Plant Pathology and Pesticide Science, Department of Applied Genetics and Pest Management, Faculty of Agriculture, Kyushu University, Fukuoka 812-8581, Japan
\end{abstract}

(Received June 24, 2004 and accepted July 13, 2004)

\begin{abstract}
Seventy-three endophytic bacterial isolates obtained from the rootstocks of Solanum sp., widely distributed in Hanoi, Vietnam, were applied to Vitek32 system for their identification. Out of these, 29 isolates were tentatively identified as Chryseobacterium indologenes, Pseudomonas fluorescens, Chryseomonas luteola, Bacillus pumilis, B. megaterium, B. sphaericus, Sphingomonas paucimobilis, Enterobacter cloacae, Pantoea agglomerans, and Staphylococcus auricularis with the similarity ranging from 97 to $99 \%$ to the species covered in the system. Eight isolates with similarity less than $97 \%$ were also tentatively put into the relevant genus. However, the remaining 36 isolates could not be identified by this system. Thirty-seven identifiable isolates were evaluated for in vitro antagonism against Ralstonia solanacearum and disease suppression of bacterial wilt of tobacco. Thirteen isolates formed growth inhibition zones around their colonies placed on lawn of $R$. solanacearum as an indicator. The variation of anti- $R$. solanacearum activity spectrum within the endophytic bacterial species and isolates suggests that there could be different antibacterial substances participated in the antagonism. Most of the endophytic bacterial isolates have not significantly shown disease suppression. There was no significant correlation between antibiotic activity in vitro and disease suppression. For example, the tobacco plants treated with the isolate KuTox708, which was the least inhibitory to $R$. solanacearum in vitro, were significantly protected from bacterial wilt infection.
\end{abstract}

\section{INTRODUCTION}

Bacterial wilt caused by Ralstonia solanacearum is a soil-borne plant disease of substantial economic importance because it is endemic in most tropical and subtropical countries. Moreover, its wide host range is ceaselessly increasing and the means of general control of the disease are still limited. Some success has been achieved by using bacterial tolerant commercial cultivars of tobacco and groundnut. However, due to the oligogenic nature of the plant resistance and to the great variation in aggressiveness of bacterial isolates from different locations around the world, alternative control measures such as biological control have been investigated with an increased interest recently.

\footnotetext{
1 Laboratory of Plant Pathology, Division of Plant Pathology and Pesticide Science, Department of Applied Genetics and Pest Management, Graduate School of Bioresource and Bioenvironmental Sciences, Kyushu University

2 San-In Kensetsu Kougyou Co., Ltd., Izumo Shimane, Japan

* Corresponding author (E-mail: nafuruya@agr.kyushu-u.ac.jp)
} 
Biological control of bacterial wilt of different crops has been reported. Kempe and Sequeira (1983) have tested avirulent strains of Pseudomonas solanacearum to induce cross protection in potato against virulent strains of the pathogen. In addition, Chen et $a l$. (1984) and Trigalet et al. (1994) reported the efficacy of an avirulent bacteriocin-producing strain of $P$. solanacearum on the control of bacterial wilt of tobacco and tomato. Furthermore, antagonistic rhizosphere bacteria such as Bacillus sp. (Celino and Gottlieb, 1952), P. fluorescens (Aspiras and de la Cruz, 1986; Anuratha and Gnanamanickam, 1990) and $P$. glumae (Furuya et al., 1991) have also been used for the suppression of bacterial wilt of tomato, potato, eggplant and banana. However, the biocontrol potential of bacterial wilt of tobacco by endophytic bacteria has not been intensively investigated.

Endophytic bacteria are bacteria living in plant tissues without doing substantive harm or gaining benefit other than securing residency (Kado, 1992). As cited extensively by Kobayashi and Palumbo (2000), endophytic bacteria have been isolated from both monocotyledonous and dicotyledonous plants that range from woody tree species to herbaceous crop plants. In the previous study (Long et al., 2003), Solanum. sp. was found to be a good source of endophytic bacteria, because many bacterial endophytes of gram positive and gram negative have been isolated from the rootstocks. In this study, identification of the endophytic bacterial isolates from Solanum sp. was conducted and their capacity for inhibiting growth of $R$. solanacearum in vitro and suppressing bacterial wilt of tobacco in vivo were also investigated.

\section{MATERIALS AND METHODS}

\section{Endophytic bacteria}

Endophytic bacteria were isolated from Solanum sp. which is widely distributed in Hanoi, Vietnam (Long et al., 2003). Seventy-three endophytic bacterial isolates (Table 1) was used in this experiment. Each isolate was cultured on the slant of YPDA medium (yeast peptone dextrose agar medium; $0.6 \mathrm{~g}$ peptone, $3 \mathrm{~g}$ dextrose, $3 \mathrm{~g}$ yeast extract and $15 \mathrm{~g}$ agar/l, $\mathrm{pH} 7.2$ ) at $30^{\circ} \mathrm{C}$ for 2 to 3 days, suspended in sterile distilled water at the concentration of ca. $10^{9} \mathrm{cfu} / \mathrm{ml}$ in test tubes, and preserved at room temperature. For long-term preservation, the bacteria were lyophilized with $10 \%$ skim-milk containing $0.05 \% \mathrm{~L}$-glutamic acid and kept at $4^{\circ} \mathrm{C}$. . Each isolate was preliminarily grown on the YPDA slant at $30^{\circ} \mathrm{C}$ for $48 \mathrm{hr}$, suspended in $10 \mathrm{ml}$ of sterile distilled water, added to $200 \mathrm{ml}$ of YP broth in Sakaguchi flask, and shaken at $30^{\circ} \mathrm{C}$ for $48 \mathrm{hr}$. The bacterium was collected by centrifugation at $6,000 \times g$ for $20 \mathrm{~min}$, and resuspended in sterile distilled water at the concentration of ca. $10^{9} \mathrm{cfu} / \mathrm{ml}$. The bacterial suspension was then used for protecting tobacco plants from the infection with $R$. solanacearum.

\section{Ralstonia solanacearum}

R. solanacerum C319 isolated from Nicotiana tabacum in Kagoshima Tobacco Experimental Station was used in this study. The strain was maintained in sterile distilled water at room temperature. Stock suspension was spread on TTC medium (triphenyl tetrazolium chloride medium; $1 \mathrm{~g}$ casamino acid, $10 \mathrm{~g}$ peptone, $5 \mathrm{~g}$ glucose, $17 \mathrm{~g}$ agar $/ \mathrm{l}$ and $5 \mathrm{ml}$ of a $1 \%$ stock solution of $2-3-5$ triphenyl tetrazolium chloride) and incubated at $30^{\circ} \mathrm{C}$ for $48 \mathrm{hr}$ in order to select virulent colonies. - Typical virulent colony was selected and 
Table 1. Origin of the endophytic bacterial isolates from the rootstocks of Solanum sp.

\begin{tabular}{|c|c|c|c|c|c|c|c|c|}
\hline \multirow{2}{*}{ Isolates } & \multicolumn{2}{|c|}{ Solanum sp. sampling } & \multirow{2}{*}{ Isolates } & \multicolumn{2}{|c|}{ Solanum sp. sampling } & \multirow{2}{*}{ Isolates } & \multicolumn{2}{|c|}{ Solanum sp. sampling } \\
\hline & Location $^{\text {a }}$ & Date & & Location & Date & & Location & Date \\
\hline KuTox101 & Thanh Xuan & $1 / 10 / 2002$ & & Thanh Tri & $22 / 10 / 2002$ & & Gia Lam & $1 / 09 / 2002$ \\
\hline KuTox102 & Thanh Xuan & $01 / 10 / 2002$ & uTox509 & Thanh Tri & $22 / 10 / 2002$ & & & $1 / 09 / 2002$ \\
\hline KuTox201 & Thanh Tri & $22 / 10 / 2002$ & KuTox510 & Thanh Tri & $22 / 10 / 2002$ & 03 & Gia Lam & $21 / 09 / 2002$ \\
\hline KuTox202 & Thanh Tri & $22 / 10 / 2002$ & & Thanh Tri & $22 / 10 / 2002$ & & & $21 / 09 / 2002$ \\
\hline KuTox203 & Thanh Tri & $22 / 10 / 2002$ & KuTox512 & Thanh Tri & $22 / 10 / 2002$ & uTox905 & Gia Lam & $21 / 09 / 2002$ \\
\hline KuTo & Thanh Tri & $22 / 10 / 2002$ & KuT & Than & $22 / 10 / 2002$ & 001 & & $3 / 05 / 2002$ \\
\hline $\mathrm{KuT}$ & Thanh Tri & $22 / 10 / 2002$ & & Than & $22 / 10 / 2002$ & & & 2002 \\
\hline KuTox302 & Thanh Tri & $22 / 10 / 2002$ & KuTox601 & Thanh Tri & $22 / 10 / 2002$ & $x 1003$ & Gia Lam & $23 / 05 / 2002$ \\
\hline & Thant & $22 / 10 / 2002$ & & & $22 / 10 / 2002$ & & & $23 / 05 / 2002$ \\
\hline $\mathrm{KuT}$ & Than & $22 / 10 / 2002$ & & Tha & $22 / 10 / 2002$ & & Lam & $23 / 05 / 2002$ \\
\hline KuTo & Thanh Tri & $22 / 10 / 2002$ & $\mathrm{Ku}^{\prime}$ & Thar & $22 / 10 / 2002$ & & Gia Lam & $23 / 05 / 2002$ \\
\hline KuT & Thanh & $22 / 10 / 2002$ & & Tha & $22 / 10 / 2002$ & & Lam & $23 / 05 / 2002$ \\
\hline KuTo & Thanh & $22 / 10 / 2002$ & & Thanh Tri & $22 / 10 / 2002$ & & & $23 / 05 / 2002$ \\
\hline KuTc & Than & $22 / 10 / 2002$ & & Tha & $22 / 10 / 2002$ & & am & $23 / 05 / 2002$ \\
\hline & Thanh Tri & $22 / 10 / 2002$ & & Tha & $22 / 10 / 2002$ & & Lam & $23 / 05 / 2002$ \\
\hline KuTc & Thanh Tri & $22 / 10 / 2002$ & & Tha & $22 / 10 / 2002$ & & Gia Lam & $23 / 05 / 2002$ \\
\hline KuT & Thanh Tri & $22 / 10 / 2002$ & KuT & Thanh Tri & $22 / 10 / 2002$ & 1303 & Lam & $23 / 05 / 2002$ \\
\hline 404 & Thanh Tri & $22 / 10 / 2002$ & & Than & $22 / 10 / 2002$ & 401 & Lam & $23 / 05 / 2002$ \\
\hline$x 501$ & Thanh Tri & $22 / 10 / 2002$ & & Than & $22 / 10 / 2002$ & & & $23 / 05 / 2002$ \\
\hline KuTox502 & Thanh Tri & $22 / 10 / 2002$ & KuTox711 & Thanh Tri & $22 / 10 / 2002$ & 1403 & Gia Lam & $23 / 05 / 2002$ \\
\hline KuTox503 & Thanh Tri & $22 / 10 / 2002$ & & Thar & $22 / 10 / 2002$ & 1501 & Gia Lam & $23 / 05 / 2002$ \\
\hline KuTox504 & Thanh Tri & $22 / 10 / 2002$ & & Thanh Tri & $22 / 10 / 2002$ & & Gia Lam & $23 / 05 / 2002$ \\
\hline KuTox505 & Thanh Tri & $22 / 10 / 2002$ & & Gia Lam & $21 / 09 / 2002$ & KuTox1503 & Gia Lam & $23 / 05 / 2002$ \\
\hline & Thanh Tri & $22 / 10 / 2002$ & KuTox802 & Gia Lam & $21 / 09 / 2002$ & KuTox1601 & Gia Lam & $23 / 05 / 2002$ \\
\hline KuTox507 & Thanh Tri & $22 / 10 / 2002$ & & & & & & \\
\hline
\end{tabular}

a) Districts in Hanoi, Vietnam

grown in PS broth (potato semi-synthetic broth; $5 \mathrm{~g}$ peptone, $15 \mathrm{~g}$ sucrose, $2 \mathrm{~g} \mathrm{Na}_{2} \mathrm{HPO}_{4}$. $12 \mathrm{H}_{2} \mathrm{O}, 0.5 \mathrm{~g} \mathrm{Ca}\left(\mathrm{NO}_{3}\right)_{2} \cdot 4 \mathrm{H}_{2} \mathrm{O}$ and decoction of $300 \mathrm{~g}$ potato/, $\mathrm{pH} 7.0$ ) with rotary shaking at $30^{\circ} \mathrm{C}$ for $48 \mathrm{hr}$. Cells were collected by centrifugation at $6,500 \times g$ for $20 \mathrm{~min}$ and resuspended in sterile distilled water to produce concentration of ca. $10^{9} \mathrm{cfu} / \mathrm{ml}$ to be used as inoculum. Five hundred $\mathrm{ml}$ of this suspension was drenched in each planter containing $7 \mathrm{~kg}$ of steam-sterilized soil.

\section{Identification of the endophytic bacterial isolates using Vitek32 system}

Seventy-three endophytic bacterial isolates were applied to automatic Vitek32 system for their identification. Each identification Vitek card comprises 30 wells which contain biochemical substrates in a dehydrated form. No additional reagents are needed, thus eliminating any risk of omission or error. Vitek identification database covers over 300 species encountered clinically and in the industrial field (Vitek ${ }^{\oplus}$, bioMérieux Inc.). In this experiment, gram negative identification + card (GNI + ) and Bacillus card were used. The results were expressed in terms of percentage of similarity to the species covered in the database of the system. Only tentatively identified isolates were used in further studies such as in vitro antagonism and pot assay. 


\section{In vitro antagonism assay}

To detect the antibacterial activity of the tentatively identified isolates, the plate chloroform method (Chen et al., 1984; Wakimoto et al., 1986) was used. A fresh culture (1-2 days) of the producer (endophytic bacterial isolate) from YPDA slant was transferred to the centre of YPDA plate. The plates were then incubated at $30^{\circ} \mathrm{C}$ for $2-3$ days. After the bacteria formed colonies several $\mathrm{mm}$ in diameter, the plate was turned upside down. A sheet of filter paper was placed in the Petri plate lid and $2 \mathrm{ml}$ of chloroform was added to it and kept at room temperature for $3 \mathrm{hr}$. After complete evaporation of chloroform, the indicator bacterial suspension (conc. ca. $10^{8} \mathrm{cfu} / \mathrm{ml}, 0.5 \mathrm{ml}$ ) was mixed with $5 \mathrm{ml}$ of $0.5 \%$ plain agar medium (melted and kept at $50^{\circ} \mathrm{C}$ ) and overlaid on the plate and incubated at $30^{\circ} \mathrm{C}$ for 2 days. If an inhibition zone appeared, its semi-diameter was measured. The experiment was conducted in duplicate.

\section{Tobacco plants}

Tobacco seeds (N. tabacum L cv. Xanthi-nc) were grown in the greenhouse conditions at temperature $20-30^{\circ} \mathrm{C}$ and watered daily. Three week-old plants were then transplanted onto cell trays. Two weeks after transplanting, healthy and uniform plants were selected for the experiment.

\section{Pot assay for bacterial wilt suppression}

Tobacco plants were removed from the cell trays and rinsed with tap water to remove loosely adhering soil. Tobacco root was dipped in endophytic bacterial suspension for $24 \mathrm{hr}$. Seedlings mock-inoculated with distilled water served as the check. Treated plants were transplanted into the soil infested with $R$. solanacearum C319 and kept in an air-conditioned greenhouse with daily irrigation. Each treatment contains 10 plants and the experiment was repeated twice. The disease severity was recorded at 5 day-intervals for 45 days using the following index: 0 : no symptom; 1 : $1-20 \%$ of the foliage wilted; 2 : $21-40 \%$ of the foliage wilted; $3: 41-60 \%$ of the foliage wilted; $4:$ more than $61 \%$ of the foliage wilted and 5: entire plant wilted or dead.

\section{Data analysis}

Data from greenhouse experiments were analyzed using an analysis of variance (ANOVA) with StatView software (SAS Institute, 1992-1998) and the protected least significant difference (PLSD) was determined. Differences with $P \leq 0.05$ were considered to be significant. All treatments in which disease ratings were significantly $(P \leq 0.05)$ lower than the check was considered to be effective.

\section{RESULTS}

\section{Identification of the endophytic bacterial isolates by Vitek32 system}

Twenty-nine isolates was tentatively identified as Chryseobacterium indologenes, P. fluorescens, Chryseomonas luteola, Bacillus pumilis, B. megaterium, B. sphaericus, Sphingomonas paucimobilis, Enterobacter cloacae, Pantoea agglomerans, and Staphylococcus auricularis with a range of similarity from $97 \%$ to $99 \%$ (Table 2). In addition, 8 isolates were tentatively identified to belong to the relevant genera with the 
Table 2. Identification of the endophytic bacterial isolates by using Vitek32 system (bioMérieux).

\begin{tabular}{|c|c|c|c|c|c|}
\hline Species & Isolates & Similarity (\%) ${ }^{a}$ & Species & Isolates & Similarity (\%) \\
\hline \multirow{6}{*}{$\begin{array}{l}\text { Chryseobacterium } \\
\text { indologenes }\end{array}$} & KuTox301 & 99 & \multirow{4}{*}{$\begin{array}{l}\text { Sphingomonas } \\
\text { paucimobilis }\end{array}$} & KuTox501 & 98 \\
\hline & KuTox302 & 98 & & KuTox706 & 99 \\
\hline & Ku'Tox402 & 99 & & KuTox707 & 99 \\
\hline & Ku'Tox403 & 99 & & KuTox709 & 99 \\
\hline & KuTox701 & 99 & \multirow{4}{*}{ Enterobacter cloacae } & KuTox201 & 99 \\
\hline & KuTox702 & 99 & & KuTox203 & 99 \\
\hline \multirow{4}{*}{ Chryseobacterium sp. } & KuTox503 & 96 & & KuTox904 & 99 \\
\hline & KuTox401 & 92 & & KuTox905 & 98 \\
\hline & KuTox308 & 92 & \multirow{7}{*}{ Pantoea agglomerans } & KuTox801 & 99 \\
\hline & KuTox703 & 92 & & KuTox802 & 98 \\
\hline \multirow{3}{*}{ Pseudomonas fluorescens } & KuTox1001 & 98 & & KuTox903 & 99 \\
\hline & KuTox1203 & 98 & & KuTox1002 & 98 \\
\hline & KuTox1303 & 98 & & KuTox 1202 & 98 \\
\hline \multirow{2}{*}{ Pseudomonas sp. } & KuTox1201 & 96 & & KuTox1503 & 97 \\
\hline & KuTox1101 & 94 & & KuTox1601 & 98 \\
\hline Chryseomonas luteola & KuTox1003 & 97 & \multirow{2}{*}{ Pantoea sp. } & KuTox901 & 96 \\
\hline Bacillus pumilis & KuTox102 & 99 & & KuTox1102 & 93 \\
\hline Bacillus megaterium & KuTox202 & 99 & Staphylococcus auricularis & KuTox708 & 97 \\
\hline Bacillus sphaericus & KuTox514 & 99 & & & \\
\hline
\end{tabular}

similarity less than $97 \%$ to the species covered in the database. However, 36 isolates could not be identified by this system.

\section{In vitro antagonism against $R$. solanacearum $\mathrm{C319}$}

Antibacterial activity against $R$. solanacearum of 37 endophytic bacterial isolates identified by the Vitek32 system to the species or genus level was investigated. Our result indicates that the anti- $R$. solanacearum activity spectrum of these isolates was greatly different depending upon the endophytic bacterial isolates (Table 3). Thirteen isolates were antagonistic against $R$. solanacearum in vitro. Three isolates (KuTox1201, KuTox905 and KuTox801) tentatively identified as Pseudomonas sp., E. cloacae and $P$. agglomerans have shown strong antagonistic activity (Fig. 1). However, 24 isolates belonging to $C$. indologenes, Chryseobacterium sp., S. paucimobilis, B. megaterium, $P$. agglomerans, $E$. cloacae and B. sphaericus did not inhibit the growth of $R$. solanacearum.

\section{Suppression of bacterial wilt of tobacco by the endophytic bacterial isolates}

Thirty-seven previously identified isolates were evaluated for bacterial wilt suppression of tobacco plant under greenhouse conditions (Table 4). Most of these isolates did not reduce significantly $(P \leq 0.05)$ the disease severity of tobacco 45 days after inoculation. Although several isolates such as KuTox1201, KuTox801 and KuTox905 exhibited a high extent of antagonistic activity against $R$. solanacearum in vitro, significant disease suppression was not found in this study. However, the isolate KuTox708 showing a low degree of antagonistic activity was remarkably suppressed the disease when compared 
with the check (Fig. 2).

Table 3. Growth inhibition of Ralstonia solanacearum C319 by the endophytic bacterial isolates.

\begin{tabular}{|c|c|c|c|c|c|}
\hline Species & Isolates & $\begin{array}{l}\text { Width of inhibition } \\
\text { zone }(\mathrm{mm})^{\mathrm{a})}\end{array}$ & Species & Isolates & $\begin{array}{c}\text { Width of inhibition } \\
\text { zone (mm) }\end{array}$ \\
\hline \multirow{6}{*}{$\begin{array}{l}\text { Chryseobacterium } \\
\text { indologenes }\end{array}$} & KuTox301 & - & \multirow{4}{*}{$\begin{array}{l}\text { Sphingomonas } \\
\text { paucimobilis }\end{array}$} & KuTox501 & - \\
\hline & KuTox302 & - & & KuTox706 & - \\
\hline & KuTox402 & - & & KuTox707 & - \\
\hline & KuTox403 & - & & KuTox709 & - \\
\hline & KuTox701 & - & \multirow{4}{*}{ Enterobacter cloacae } & Ku'Tox201 & - \\
\hline & KuTox702 & - & & KuTox203 & - \\
\hline \multirow{4}{*}{ Chryseobacterium sp. } & Ku'Tox503 & - & & KuTox904 & + \\
\hline & KuTox401 & - & & KuTox905 & $+1+$ \\
\hline & KuTox308 & - & \multirow{7}{*}{ Pantoea agglomerans } & KuTox801 & $+1+$ \\
\hline & KuTox703 & - & & KuTox802 & ++ \\
\hline \multirow{3}{*}{$\begin{array}{l}\text { Pseudomonas } \\
\text { fluorescens }\end{array}$} & KuTox1001 & + & & KuTox903 & - \\
\hline & KuTox1203 & + & & KuTox1002 & - \\
\hline & KuTox1303 & + & & KuTox1202 & - \\
\hline \multirow{2}{*}{ Pseudomonas sp. } & KuTox1201 & $+1+$ & & KuTox1503 & - \\
\hline & KuTox1101 & + & & KuTox1601 & - \\
\hline Chryseomonas luteola & KuTox 1003 & + & \multirow{2}{*}{ Pantoea sp. } & KuTox901 & - \\
\hline Bacillus pumilis & KuTox102 & $(+)$ & & KuTox1102 & + \\
\hline Bacillus megaterium & KuTox202 & - & Staphylococcus auricularis & KuTox708 & $(+)$ \\
\hline Bacillus sphaericus & KuTox514 & - & & & \\
\hline
\end{tabular}

a) Inhibition zone semi-diameter was measured after $24 \mathrm{hr}$ of incubation at $30^{\circ} \mathrm{C}$; Inhibition zone semi-diameter index: $+1+,>10 \mathrm{~mm} ;++, 5-10 \mathrm{~mm} ;+,<5 \mathrm{~mm} ;(+)$, doubtful; -, no zone of inhibition.

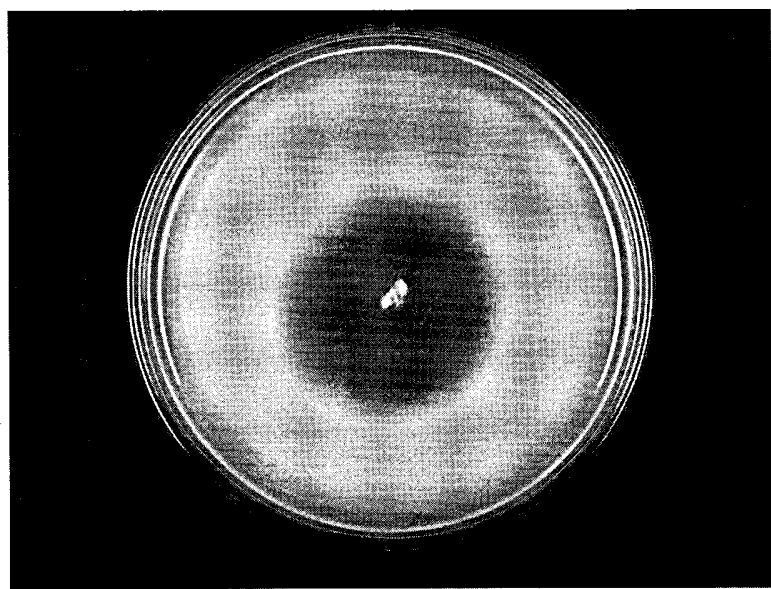

Fig. 1. Growth inhibition zone formed by the endophytic bacterial isolate Ku'Tox905 on the lawn of Ralstonia solanacearum C319. 
Table 4. Protection efficacy of bacterial wilt of tobacco by the endophytic bacterial isolates.

\begin{tabular}{ccccccc}
\hline \multirow{2}{*}{ Isolates } & \multicolumn{2}{c}{ Mean of disease severity ${ }^{\text {a }}$} & & \multirow{2}{*}{ Isolates } & \multicolumn{2}{c}{ Mean of disease severity } \\
\cline { 2 - 3 } & Treatment & Check & & & Treatment & Check \\
\hline KuTox301 & 2.2 & 3.1 & & KuTox708 & $1.5^{*}$ & 3.1 \\
KuTox302 & 2.0 & 2.0 & & KuTox501 & 1.8 & 2.8 \\
KuTox402 & 2.7 & 3.1 & & KuTox706 & 2.0 & 2.3 \\
KuTox403 & 2.8 & 3.1 & & KuTox707 & 4.5 & 4.7 \\
KuTox701 & 2.2 & 2.0 & & KuTox709 & 1.3 & 2.3 \\
KuTox702 & 3.0 & 2.8 & & KuTox201 & 2.0 & 2.3 \\
KuTox503 & 3.0 & 3.6 & & KuTox203 & 3.5 & 2.7 \\
KuTox401 & 2.3 & 2.0 & & KuTox904 & 1.0 & 1.5 \\
KuTox308 & 2.7 & 3.6 & & KuTox905 & 1.2 & 2.3 \\
KuTox703 & 4.0 & 2.0 & & KuTox801 & 1.8 & 1.9 \\
KuTox1001 & 2.1 & 1.9 & & KuTox802 & 0.6 & 1.5 \\
KuTox1203 & 1.9 & 2.3 & & KuTox903 & 2.6 & 2.3 \\
KuTox1303 & 0.9 & 1.7 & & KuTox1002 & 1.9 & 3.0 \\
KuTox1201 & 2.0 & 2.3 & & KuTox1202 & 1.8 & 2.7 \\
KuTox1101 & 1.3 & 2.5 & & KuTox1503 & 1.8 & 2.7 \\
KuTox1003 & 1.3 & 2.0 & KuTox1601 & 1.8 & 2.7 \\
KuTox102 & 2.7 & 2.1 & KuTox901 & 1.5 & 2.3 \\
KuTox202 & 1.6 & 2.3 & KuTox1102 & 2.8 & 2.7 \\
KuTox514 & 1.5 & 2.7 & & & \\
\hline
\end{tabular}

a) Disease severity was rated using a 0 (no disease) to 5 (entire plant wilted) rating scale 45 days after inoculation.

* Significantly different from the check (Determined by the Fisher's PLSD test $P \leq 0.05$ ).

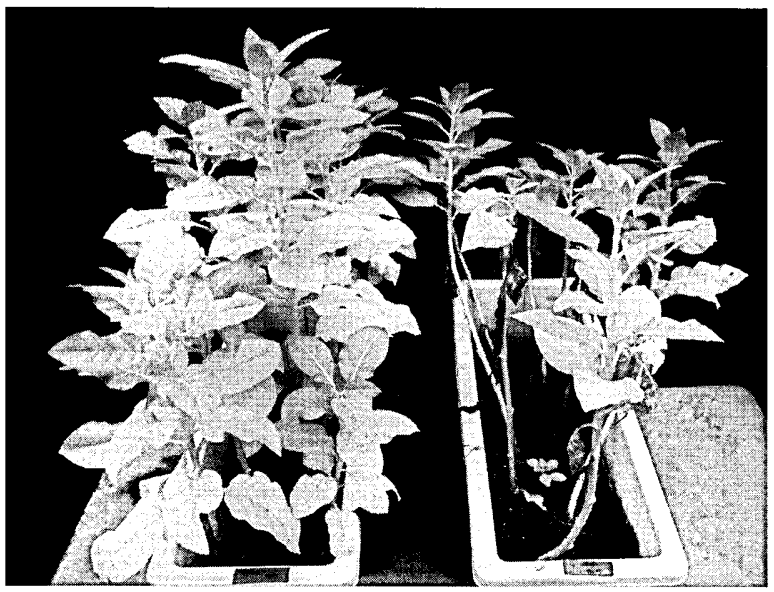

Fig. 2. Suppression of bacterial wilt of tobacco by the endophytic bacterial isolate KuTox708. 


\section{DISCUSSION}

Endophytic bacteria have been found to be associated with the root of numerous plant species, with most being members of common bacterial genera such as Pseudomonas, Bacillus, Corynebacterium (Lalande et al., 1989; Gardner et al., 1982; Jacobs et al., 1985), Burkholderia, Enterobacter (McInroy and Kloepper, 1995; Gardner et al., 1982). In our previous paper (Long et al., 2003), diversity in endophytic bacterial population in the root of Solanum sp. was clarified. For a rapid identification of the endophytic bacterial isolates, Vitek32 system was used in this study. The endophytic bacterial isolates from Solanum sp. were tentatively identified as Bacillus, Pseudomonas, Enterobacter, Pantoea, Sphingomonas, Chryseomonas, Staphylococcus and Chryseobacterium which is the most prominent genus. Study for more accurate identification of the endophytic bacterial isolates including 36 unidentifiable isolates is in progress.

Among 37 tentatively identified isolates of endophytic bacteria, 13 isolates exhibited growth inhibition of $R$. solanacearum in vitro. In particular, the identified isolates of Pseudomonas sp. that has been known to be one of the most antibiotic producers in the rhizosphere (Weller and Cook, 1983; Brisbane and Rovira, 1988) showed anti-R. solanacearum activity. The inhibitory spectrum against $R$. solanacearum varied depending upon isolates of endophytic bacteria, suggesting that various antibiotics may be involved in the formation of inhibition zones.

Antibiotic production could play a significant role in disease suppression, since there was relationship between the level of in vitro antibiosis and in vivo suppression of bacterial wilt (Chen et al., 1984; Trigalet et al., 1994). In this study, however, the isolate with strong antagonistic activity against $R$. solanacearum in vitro has shown a low level of disease suppression in tobacco plant under greenhouse conditions. On the other hand, although KuTox708 did not produce a clear inhibition zone against the pathogen in vitro, the isolate protected tobacco plants from bacterial wilt caused by $R$. solanacearum. Significant correlation between in vitro antagonism and disease suppression in vivo was not found in this study. The role of antibiotic produced by the endophytic bacterial isolates seems to be slight in the mechanisms of disease suppression. Kempe et al. demonstrated that the induced resistance by pre-treatment with pseudomonads may be involved in the mechanism of suppression of bacterial wilt of potato. The disease suppression shown in this experiment may be also the result of systemic resistance induced by KuTox708. Further studies are needed to clarify the mechanisms of disease suppression in detail.

\section{REFERENCES}

Anuratha, C. S. and S. S. Gnanamanickam 1990 Biological control of bacterial wilt caused by Pseudomonas solanacearum in India with antagonistic bacteria. Plant Soil, 124: 109-116

Aspiras, R. B. and A. de la Cruz 1985 Potential biological control of bacterial wilt in tomato and potato with Bacillus polymyxa Fu6 and Pseudomonas fluorescens. In "Bacterial Wilt Disease in Asia and the South Pacific", ACIAR Proceedings No. 13 ed. by G. J. Persley, pp. 89-92

Brisbane, P. G. and A. D. Rovira 1988 Mechanisms of inhibition of Gaeumannomyces graminis var. tritici by fluorescent pseudomonads. Plant Pathol., 37: 104-111

Celino, M. S. and D. Gottlieb 1952 Control of bacterial wilt of tomato by Bacillus polymyxa. 
Phytopathology, 42: 4

Chen, W. Y. and E. Echandi 1984 Effects of avirulent bacteriocin-producing strains of Pseudomonas solanacearum on the control of bacterial wilt of tobacco. Plant Pathol., 33: 245-253

Furuya, N., Y. Kushima, K. Tsuchiya, N. Matsuyama and S. Wakimoto 1991 Protection of tomato seedlings by pre-treatment with Pseudomonas glumae from infection with Pseudomonas solanacearum and its mechanisms. Ann. Phytopath. Soc. Jpn., 57(3): 363-370

Gardner, J. M., A. W. Feldman and R. M. Zablotowicz 1982 Identity and behavior of xylem-residing bacteria in rough lemon roots of Florida citrus trees. Appl. Environ. Microbiol., 43: 1335-1342

Hallmann, J., A. Quadt-Hallmann, W. F. Mahaffee and J. W. Kloepper 1997 Bacterial endophytes in agricultural crops. Can. J. Microbiol., 43: 895-914

Jacobs, M. J., W. M. Bugbee and D. A. Gabrielson 1985 Enumeration, location, and characterization of endophytic bacteria within sugar beet roots. Can. J. Bot., 63: 1261-1265

Kado, C. I. 1992 Plant Pathogenic Bacteria. In "The prokaryotes". ed. by A. Balows, H. G. Trüper, M. Dworkin, W. Harder and K. H. Schleifer. Springer-Verlag, New York, pp. 660-662

Kempe, J. and L. Sequeira 1983 Biological control of bacterial wilt of potatoes: attempts to induce resistance by treating tubers with bacteria. Plant Dis., 67: 499-503

Kobayashi, D. Y. and J. D. Palumbo 2000 Bacterial endophytes and their effects on plants and uses in agriculture. In "Microbial endophytes" ed. by C. W. Bacon and J. F. White, Marcel Dekker Inc., New York, pp. 199-233

Lalande, R., N. Bissonnette, D. Coutlee and H. Antoun 1989 Identification of rhizobacteria from maize and determination of their plant-growth promoting potential. Plant Soil, 115: 7-11

Long, H. H., N. Furuya, D. Kurose, M. Takeshita and Y. Takanami 2003 Isolation of endophytic bacteria from Solanum sp. and their antibacterial activity against plant pathogenic bacteria. J. Fac. Agr., Kyushu Univ., 48(1-2): 21-28

McInroy, J. A. and J. W. Kloepper 1995 Survey of indigenous bacterial endophytes from cotton and sweet corn. Plant Soil, 173: 337-342

Trigalet, A., P. Frey and D. Trigalet-Demery 1994 Biological control of bacterial wilt caused by Pseudomonas solanacearum: State of the art and understanding. In "Bacterial wilt: The disease and its causative agent, Pseudomonas solanacearum" ed. by A. C. Hayward and G. L. Hartman. CABI, pp. 225-231

Wakimoto, S., K. Hirayae, K. Tsuchiya, Y. Kushima, N. Furuya and N. Matsuyama 1986 Production of antibiotics by plant pathogenic Pseudomonads. Ann. Phytopath. Soc. Jpn., 52: 835-842

Weller, D. M. and R. J. Cook 1983 Suppression of take-all of wheat by seed treatment with fluorescent pseudomonads. Phytopathology, 73: 463-469 